\title{
EXPERIMENTAL INVESTIGATION OF TIN OXIDE BLOCKING LAYER FOR MONOLITHIC DYE SENSITIZED SOLAR CELLS
}

\author{
Jeffrey .C. Amaechi \\ Department of Physics, \\ Ignatius Ajuru University of Education Rumuolumeni, \\ Rivers State, Nigeria. \\ Email: amaechijeffrey07@gmail.com
}

\begin{abstract}
This research work was on experimental investigation of Tin oxide blocking layer for dye-sensitized solar with objective targeted at improved power conversion, efficiency and charge recombination that contribute to low current in dye sensitized solar cells. Dye-sensitized solar cells (DSSCs) built upon mesoporous titanium dioxide sensitized with organic dye extracted from dried Hibiscus sabdariffa with three different materials used as blocking layers were fabricated. The dye extract and active layers were characterized by UV-vis spectrophotometer, with the $\mathrm{TiO}_{2}$ sensitized with dye layer showing a band gap of $3.0 \mathrm{eV}$, and hence could absorb incident solar radiation beyond the Ultraviolet region. Photoelectrochemical properties of the DSSCs were determined using the Newport solar simulator. The best performance among the DSSCs fabricated was obtained for the dye sensitized solar cell fabricated with titanium dioxide as blocking layer with a conversion efficiency of $2.88 \%$. The investigation showed that dye sensitized solar cells fabricated with Tin oxide blocking layer showed lower conversion efficiency when compared to dye sensitized solar cells fabricated with titanium dioxide as blocking layer.
\end{abstract}

Keywords: Titanium dioxide, optical properties, dye sensitized solar cell (DSSCs), band gap, Hibiscus sabdariffa, monolithic, solar simulation properties.

\section{INTRODUCTION}

Photovoltaic technology is an emerging market with excessive capabilities for contemporary and imminent energy foundations, dye-sensitized solar cells is the forthcoming advancement of photovoltaic technology. To transit in the direction of complete saleable product, some difficulties persist with respect to the additional perfections as regards the gadget solidity, proficiency, and also lessening of the materials and industrial cost.

Dye-sensitized Solar cells are photo-voltaic gadgets capable of transforming evident light from the sun into electricity, and in addition are centered on a permeable tinny film of an extensive band-gap semiconductor oxide altered by colorant (Chergui et al, 2015). The manufacturing cost of Dye-sensitized Solar cells, which are third-generation solar cells is much less than that of silicon solar cells which have succeeded in electricity renovation proficiencies extending from $15 \%$ to $20 \%$; nevertheless, applicable extraordinary assembling budget plus the habit of using harmful substances in the production of extremely refined silicon associated with the industrial procedure has stirred the exploration aimed at having alternative in the dye-sensitized solar cell 
which is a naturally friendly and a very cheap budget solar cell. Dye-sensitized solar cells have expanded weighty consideration since (Nazerruddin et al, 2001; O'Regan and Gratzel, 1991) reported an extraordinarily high conversion efficiency of nearly $10 \%$ using nanocrystalline mesoporous Titanium dioxide $\left(\mathrm{TiO}_{2}\right)$ film (O'Regan and Gratzel, 1991). Yet, these biological solar cells are still limited in low power conversion, proficiencies, and charge recombination is one of the principle explanations behind low current in dye-sensitized solar cells, so the performance of (DSSCs) is seriously decreased. A compact layer has been corroborated hypothetically and practically operational to wedge the electron recombination through the ancillary path. A compacted hindering deposit amongst the accompanying electron and the nanocrystalline Titanium dioxide $\left(\mathrm{TiO}_{2}\right)$ layer can viably forestall recombination at the cathode/electrolyte interface as experimentally investigated in this study.

\section{MATERIALS AND METHODS}

\section{DSSC Assembling}

The photoanode was prepared first by etching the fluorine doped tin oxide (FTO) glass (Solaronics) using electro-etching method, followed with a deposition of a blocking layer. The blocking layer was deposited to FTO glass substrate from a precursor of total volume of 40ml, which has a concentration of $0.1 \mathrm{~m}$ of titanium isopropoxide, $0.4 \mathrm{~m}$ of acetylacetone and methanol using the spin coating method, and subsequently annealed to $450^{\circ} \mathrm{C}$ for 30 minutes. The Titanium dioxide $\left(\mathrm{TiO}_{2}\right)$ (usually a paste) was deposited onto the fluorine doped tin oxide (FTO) glass substrate by 'screen printing method'. On top of the glass substrates, a layer of (solaronix Ti-Nanoxide D/SP) screen printable paste was applied, outlining it on the active area. The sample was annealed gradually from $150^{\circ} \mathrm{C}$ to $300^{\circ} \mathrm{C}$ and then finally $450^{\circ} \mathrm{C}$. Once it is annealed to $150^{\circ} \mathrm{C}$, the samples were left to dwell for 10 minutes and then annealed to $300^{\circ} \mathrm{C}$ and left to dwell for another 10 minutes and finally annealed to $450^{\circ} \mathrm{C}$. After annealing, the samples were allowed to cool down for 30minutes. On top of the fluorine doped tin oxide (FTO) glass substrates, a layer of Zirconium dioxide (Solaronix Zr-nanoxide Z/SP) screen printable paste was deposited using the screen printing method. This layer insulates the titanium dioxide mesoporous layer from the counter electrode. The sample was annealed to $400^{\circ} \mathrm{C}$ for 30 minutes and allowed to cool down for 30minutes. Propanol and cotton wool was used to clean the screen printing machine to rid it off any particle of the previous layer deposited. This layer becomes the negative terminal of the monolithic dye sensitized solar cells.

The counter electrode was prepared by screen printing a platinum $(\mathrm{Pt})$ catalyst gel coating on the FTO glass substrate. A thin layer of platinum $(\mathrm{Pt})$ was deposited on the glass substrates by screen printing (Solaronics platisol T/SP paste), which acts as a catalyst and annealed to $400^{\circ} \mathrm{C}$ for 30 minutes. A layer of (Solaronix Elcocarb G/SP) screen printable paste was deposited using screen printing method on the active area. The elcocarb is just a conducting material and was printed to 
bridge the two conductive layers as it helps to transfer voltage to the back layer, and it becomes the positive terminal of the monolithic dye sensitized solar cells. The samples were then annealed to $400^{\circ} \mathrm{C}$ for 30 minutes, activating the elcocarb layer for working and then allowed to cool down to $100^{\circ} \mathrm{C}$.

The cell was soaked overnight at room temperature in the dye extract, for it to absorb into all the layers. It was then stored away from light (in the dark); after 12 hours, the cells were brought out and rinsed with water and dried at $60^{\circ} \mathrm{C}$.

\subsection{Optical Characterization}

A (UV 752) ultraviolet-visible-Near Infra-Red (UV-VIS-NI) spectrophotometer U.K was used to carry out the optical study of the cells at the wavelength interval of $230 \mathrm{~nm}$ to $1100 \mathrm{~nm}$. Absorbance values were obtained using the spectrophotometer and other optical properties like transmittance, reflectance, refractive index, absorption coefficient, extinction coefficient and energy band gap were evaluated.

\subsection{Solar Simulation Characterization}

The IV characteristics curves of the fabricated DSSCs were measured under an illumination of $100 \mathrm{~mW} / \mathrm{cm}^{2}$ using a Newport solar simulator (model 94043A), and I.V acquired by a Keithley 2400 source meter. Cell surface area is $1 \mathrm{~cm} \mathrm{x} 1 \mathrm{~cm}$.

\section{Preparation of natural dye solution}

Dried calyxes of Hibiscus sabdariffa were used as sensitizers of the dye sensitized solar cell fabricated. They were washed with distilled water, and the dye solution was prepared by boiling the hibiscus sabdariffa calyxes in 40cl of water to boiling temperature. The dye solution was allowed to cool down for 3 hours and the cell was soaked overnight at room temperature in the dye extract, for it to absorb into all the layers. It was then stored away from light (in the dark); after 12 hours, the cell was brought out and rinsed with water and dried at $60^{\circ} \mathrm{C}$.

\section{RESULTS AND DISCUSSION}

\section{Optical Properties}

The optical absorption spectrum (Figure 1) shows that the hibiscus sabdariffa dye- $\mathrm{TiO}_{2}$ photoanode noticeably absorbed light beyond the UV region. Hence, the natural dye significantly enhanced the absorbance of the wide-band titanium dioxide which alone cannot absorb visible light. 


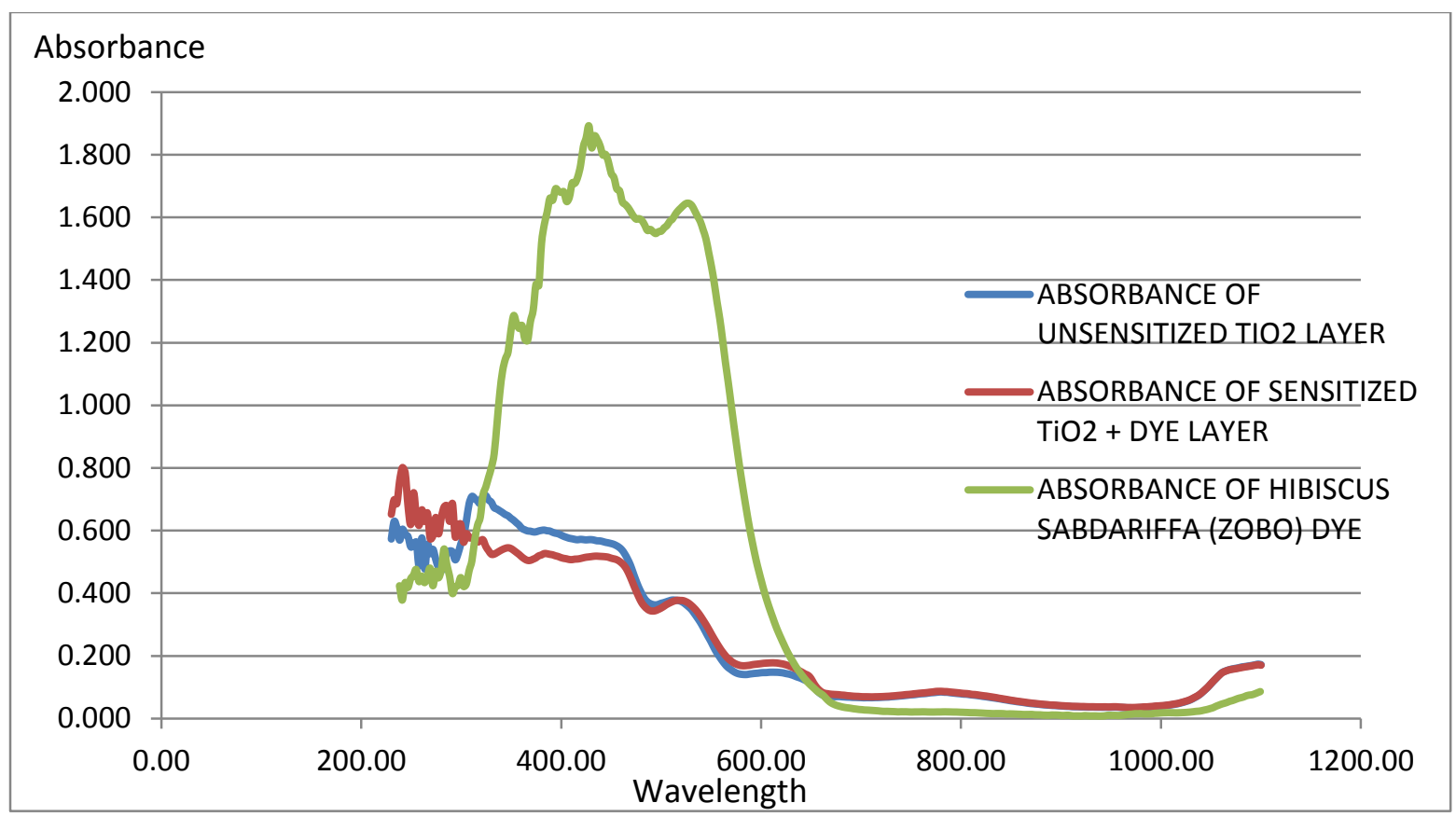

Figure 1 Uv-vis- Absorbance spectra of TiO2 layer, TiO2 + dye layer and Dye (hibiscus sabdariffa) alone.

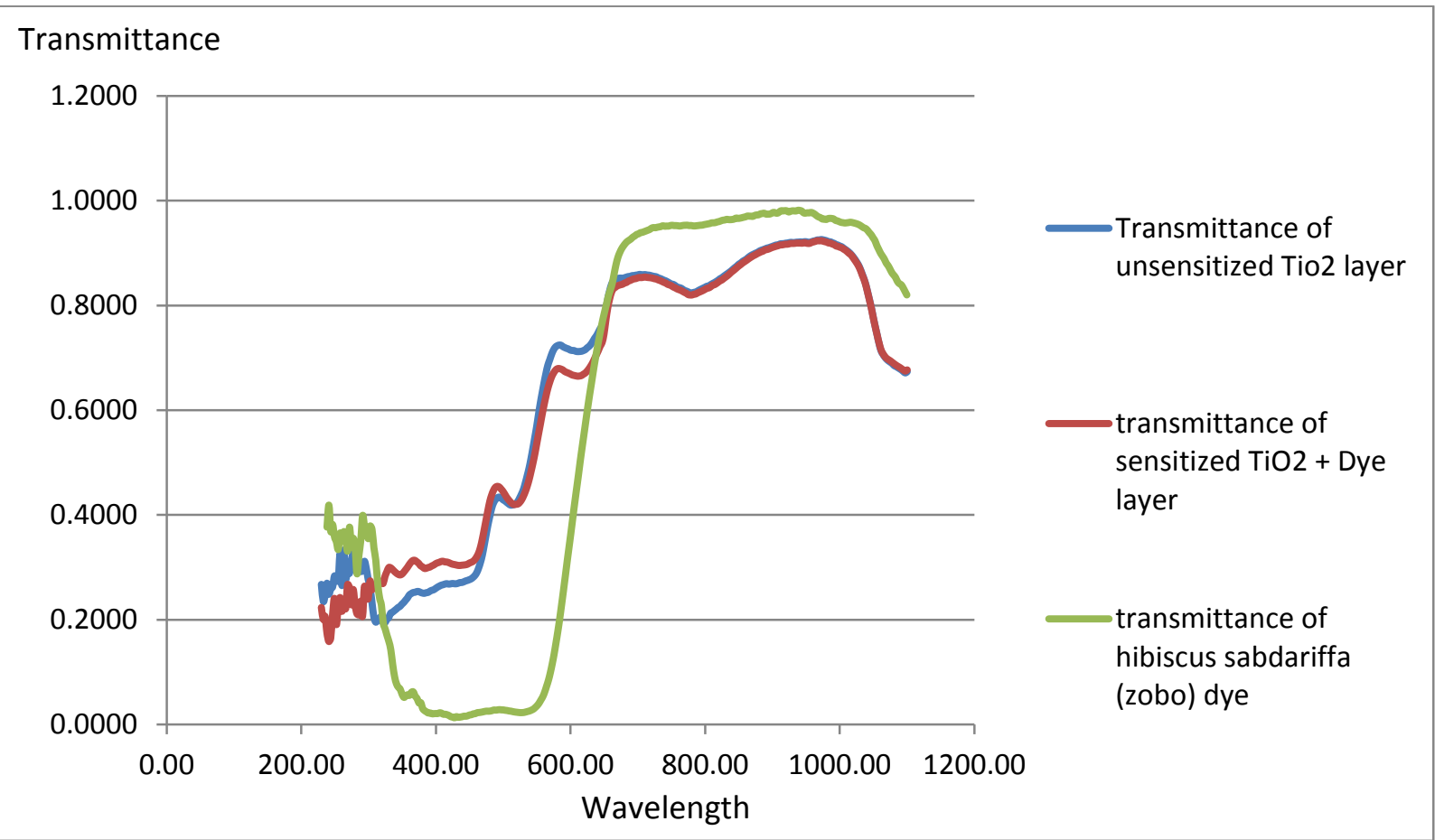

Figure 2 Uv-vis- Transmittance spectra of TiO2 layer, TiO2 + dye layer and Dye (hibiscus sabdariffa) alone. 
Figure 2 represents the transmittance spectrum while Figure 3 is the direct band-gap of hibiscus sabdariffa-doped $\mathrm{TiO} 2$, The value was extrapolated to be $3.0 \mathrm{eV}$.

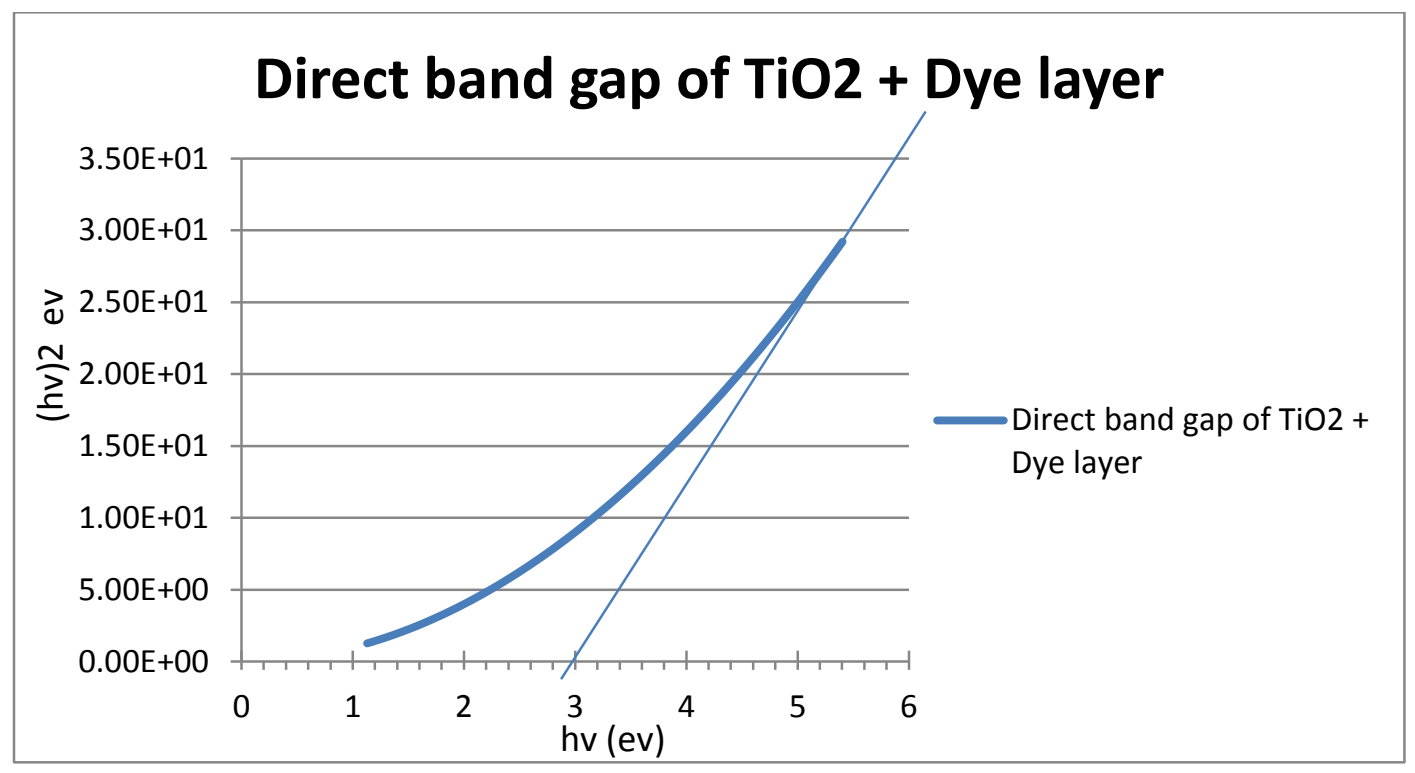

Figure 3 Direct band-gap of hibiscus sabdariffa-doped $\mathrm{TiO}_{2}$

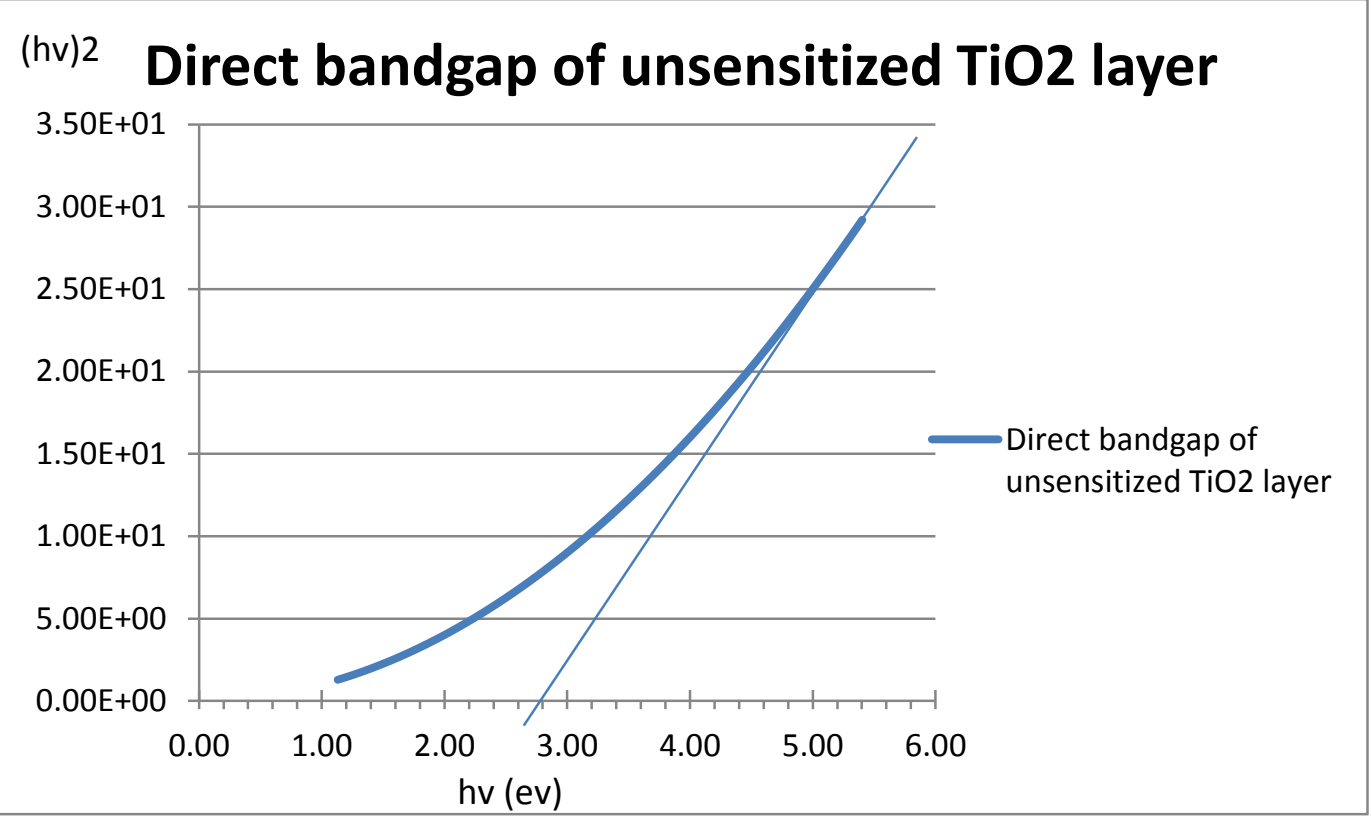

Figure 4. Direct band-gap of un-sensitized TiO2 layer

The direct optical band-gap for the un-sensitized $\mathrm{TiO} 2$ layer was estimated to be $2.7 \mathrm{ev}$ by extrapolating the linear portion of the curve (hv) $)^{2}$ against (hv). 


\section{Solar Simulation (Photoelectrochemical) Properties}

The I.V measurement of the Dye Sensitized Solar Cells sensitized (DSSCs) with extracts of Hibiscus sabdariffa (dye) are illustrated in figure 4.

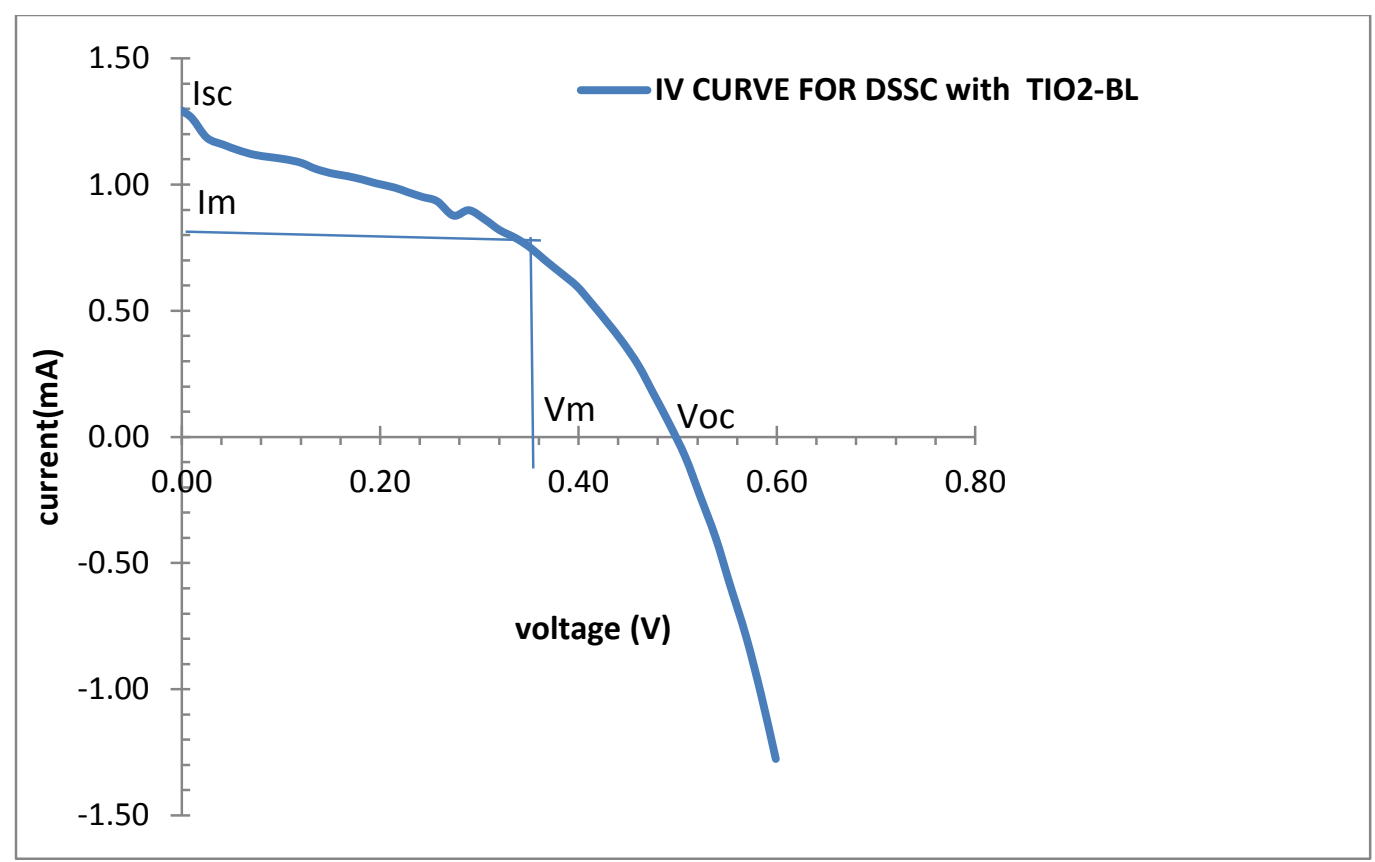

Figure 5. The I-V curve of the cell sensitized with hibiscus sabdariffa dye

Figure 5 shows the current-voltage characteristics of a DSSC based on the hibiscus sabdariffadyed electrode under solar illumination of $100 \mathrm{~mW} / \mathrm{cm}^{2}$.

The cell parameters obtained were; open circuit voltage $(0.50 \mathrm{~V})$, short circuit current $\left(1.3 \mathrm{~mA} / \mathrm{cm}^{2}\right)$, fill factor $(0.44)$ and photoelectric conversion efficiency $(2.88 \%)$.

Hibiscus sabdariffa (dye) are illustrated in figure 5 and 6. 
Current

\section{CURVE FOR DSSC (TiO2 undoped)}

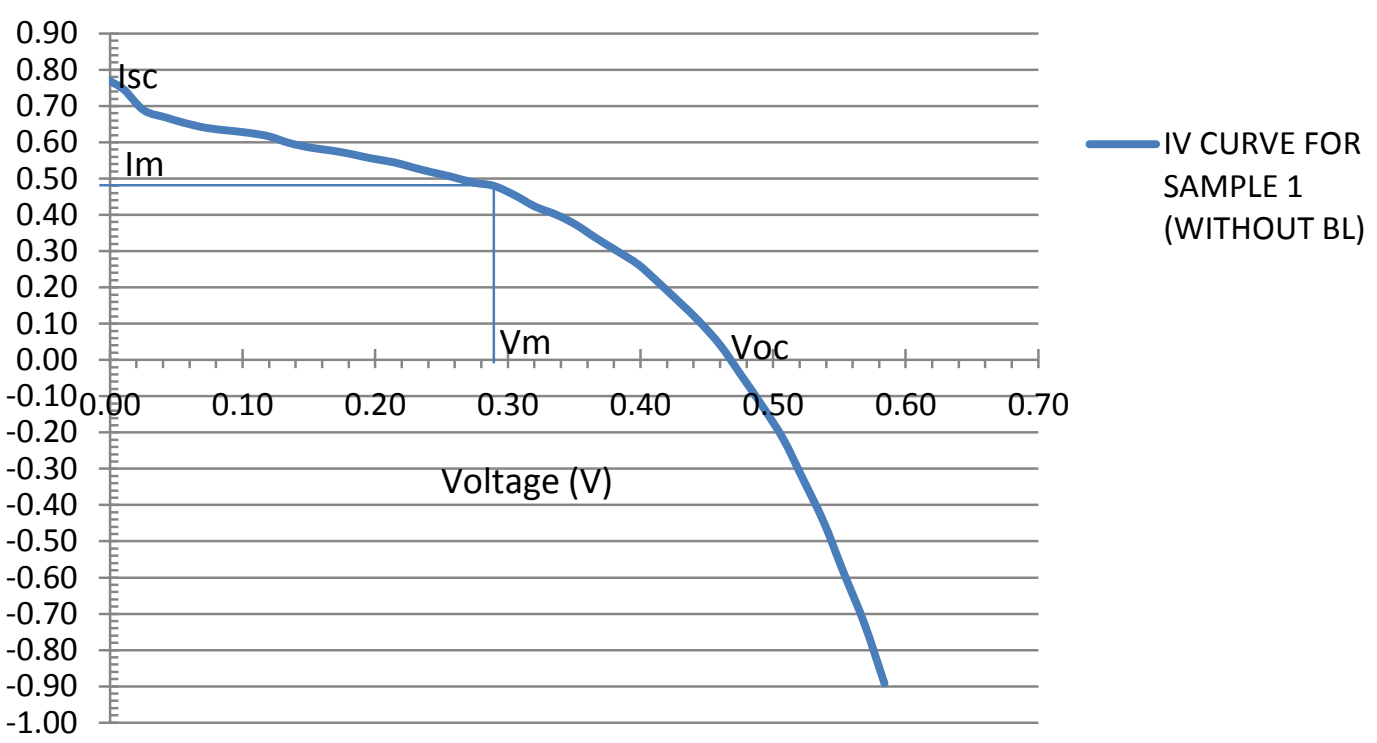

Figure 6. I V curve for Sample with Un-doped TiO2

Table1. Photovoltaic parameters of the fabricated Dye sensitized solar cells (DSSCs).

\begin{tabular}{|l|l|l|l|l|l|l|}
\hline Sample & $\begin{array}{l}\text { Voc } \\
\text { Isc }\end{array}$ & $\begin{array}{l}\text { Vm } \\
(\mathbf{m A})\end{array}$ & $\begin{array}{l}\mathbf{I m} \\
(\mathbf{V})\end{array}$ & $\mathbf{F F}$ & $\mathbf{\eta}$ \\
\hline 1.(un-doped TiO2) & 0.47 & 0.78 & 0.29 & 0.48 & 0.38 & 1.34 \\
\hline 2.(Doped TiO2) & 0.50 & 1.3 & 0.36 & 0.8 & 0.44 & 2.88 \\
\hline
\end{tabular}

\section{CONCLUSION}

In conclusion, three samples of dye-sensitized solar cells were fabricated and their uv-vis absorbance spectra, transmittance spectra, reflectance spectra, refractive index, and absorption coefficient were determined using a (UV 752) ultraviolet-visible near infra-red (UV-VIS-NI) spectrophotometer. The thickness and electrical properties of the FTO used in fabricating the dye-sensitized solar cell were determined using Hall Effect measurement system HMS-3000, Ecopia. The solar simulation properties of the fabricated DSSCs were ascertained using a Newpot solar simulator (Model 94043A) and I.V acquired by a Keithley 2400 source meter. Cell 
surface area was $1 \mathrm{~cm} \mathrm{X} 1 \mathrm{~cm}$, and short circuit current (Isc) and open-circuit voltage (Voc) values were obtained using Keithley 2400 source meter and other solar cell properties like fill factor $(\mathrm{FF})$ and efficiency were also evaluated.

The results from the investigation revealed that the best performance was obtained for the dye sensitized solar cell fabricated with mesoporous titanium dioxide (TiO2) as blocking layer with $\mathrm{Voc}=0.5 \mathrm{~V}, \mathrm{Isc}=1.3 \mathrm{~mA} / \mathrm{cm}^{2}, \mathrm{Vm}=0.36 \mathrm{~V}$,

$\operatorname{Im}=0.80 \mathrm{~mA} / \mathrm{cm}^{2}, \mathrm{FF}=0.44$ and $\dot{\eta}=2.88 \%$.

This implies that Tin oxide is not a good material for application as a blocking layer in dye sensitized solar cells (DSSCs), except it is optimized.

\section{REFERENCES:}

1.Chergui, M., Santomauro, F. G., Lübcke, A., Rittmann, J., Baldini, E., Ferrer, A., \& Silatani, M. (2015).

Femtosecond X-ray absorption study of electron localization in photoexcited anatase $\mathrm{TiO}_{2}$. Scientific

Reports, 5. https://doi.org/10.1038/srep14834

2.Grant, C. D., Adam, M. S., Greg, P. S., Janusz, K., Laren, M. T., \& Jin, Z. Z. (2002).

Characteriztion of nanocrystalline and thin film $\mathrm{TiO}_{2}$ Solar cell with Poly (3-undecyl 2, 2-bithiophene) as a sensitizer and hole conductor. Journal of Electroanalytical Chemistry, 522 (1), 40-48, https://doi.org/10.1016/S 0022-0728(01)00715-x

3.Grätzel, M. (2004). Conversion of sunlight to electric power by nanocrystalline dye-sensitized solar cells, Journal of Photochemistry and Photobiology A: Chemistry, 164 (1-3), 3-14.

4.Imran, K., Andrew, H., \& Christos, F. (2013). A study on the optimization of dyesensitized solar cells. Graduate theses and dissertations.

http://scholarcommons.usf.edu/etd/4519.

5.Ito, S. T. N., Murakami, P., Comte, P., Liska, C., Grätzel, M. K., \& Nazeeruddin, M. (2008).Fabrication of thin film dye sensitized solar cells with solar to electric power conversion efficiency over 10\%, Thin Solid Films, 516 (14), 4613-4619. 
6.Lokhande, P., Patil, S., \& Uplane, M. D. (2002). Deposition of highly oriented ZnO films by spray pyrolysis and their structural, optical and electrical characterization. International Journal of Materials Engineering, 2 (1), 12-17. https://doi.org/10.1016/S0167-577X(02)00832-7

7.Nazeeruddin .M.K, P. Péchy, T. Renouard, S. M. Zakeeruddin, R. Humphry-Baker, P. Comte, P. Liska, L. Cevey, E. Costa, V. Shklover, L. Spiccia, G. B. Deacon, C. A. Bignozzi, \& M. Grätzel, (2001). Engineering of Efficient Panchromatic Sensitizers for Nanocrystalline $\mathrm{TiO}_{2}$-Based Solar Cells, J. Am. Chem. Soc.,123 (8), 1613-1624.

8.O'Regan, B., \& Grätzel, M. (1991). A low-cost, high-efficiency solar cell based on dyesensitized colloidal TiO2 films. Nature, 353, 737- 40.

9.Ozuomba, J. O., Ugwu, J. E., Azubuike, P., \& Ekwo, I. (2015). The Optical properties of anthocyan doped nanocrystalline $\mathrm{TiO}_{2}$ and the photovoltaic efficiency on DSSC. Der Chemic Sinica, 6 (11), 42 48.

10.Usami, A., \& Ozaki, H. (2001). Computer simulations of charge transport in dye-sensitized nanocrystalline photovoltaic cells. The Journal of Physical Chemistry B; 105 (45), 77- 83.

11.Wali, Q., Fakharuddin A., \& Jose. R., (2015). Tin oxide as a photoanode for dye-sensitised solar cells: current progress and future challenges. Journal of Power Sources, 293 (10)39 - 52. Wang, L., Kang, B., Wang, P., \& Qiu, Y. (2006). Review of recent progress in solid-state dye-sensitized solar cells. Solar Energy Materials and Solar Cells, 90 (5), 49 